\title{
Nuclear Translocation of Argonaute 2 in Cytokine-Induced Senescence
}

\author{
Maximilian Rentschler ${ }^{\mathrm{a}} \quad$ Yan Chen $^{\mathrm{a}} \quad$ Jana Pahl $^{\mathrm{a}} \quad$ Laura Soria-Martinez $^{\mathrm{a}}$ \\ Heidi Braumüller ${ }^{a} \quad$ Ellen Brennera ${ }^{a}$ Oliver Bischof ${ }^{b, c, d} \quad$ Martin Röcken ${ }^{a}$ \\ Thomas Wiedera
}

aDepartment of Dermatology, University Medical Center Tübingen, Eberhard Karls University, Tübingen, Germany, 'Institut Pasteur, Nuclear Organisation and Oncogenesis Unit, Department of Cell Biology and Infection, Paris, 'INSERM, U993, Paris, 'Equipe Labellisée Fondation ARC pour la recherche sur le cancer, Paris, France

\section{Key Words}

Cellular Senescence - Interferons - Stable Growth Arrest • Tumor Necrosis Factor - Tumor Surveillance

\begin{abstract}
Background/Aims: Cellular senescence, or permanent growth arrest, is known as an effective tumor suppressor mechanism that can be induced by different stressors, such as oncogenes, chemotherapeutics or cytokine cocktails. Previous studies demonstrated that the growthrepressing state of oncogene-induced senescent cells depends on argonaute protein 2 (Ago2)-mediated transcriptional gene silencing and Ago2/Rb corepression of E2F-dependent cell cycle genes. Cytokine-induced senescence (CIS) likewise depends on activation of the p16 $16^{\text {Ink4a }} / \mathrm{Rb}$ pathway, and consecutive inactivation of the E2F family of transcription factors. In the present study, we therefore analyzed the role of Ago2 in CIS. Methods: Human cancer cell lines were treated with interferon-gamma (IFN- $\gamma$ ) and tumor necrosis factor (TNF) to induce senescence. Senescence was determined by growth assays and measurement of senescence-associated $\beta$-galactosidase (SA- $\beta$-gal) activity, Ago2 translocation by Ago2/ Ki67 immunofluorescence staining and western blot analysis, and gene transcription by quantitative polymerase chain reaction (qPCR). Results: IFN- $\gamma$ and TNF permanently stopped cell proliferation and time-dependently increased SA- $\beta$-gal activity. After $24-48 \mathrm{~h}$ of cytokine treatment, Ago2 translocated from the cytoplasm into the nucleus of Ki67-negative cells, an effect which was shown to be reversible. Importantly, the proinflammatory cytokine cocktail suppressed Ago2-regulated cell cycle control genes, and siRNA-mediated depletion of Ago2 interfered with cytokine-induced growth inhibition. Conclusion: IFN- $\gamma$ and TNF induce a stable cell cycle arrest of cancer cells that is accompanied by a fast nuclear Ago 2 translocation




\section{Cellular Physiology Cell Physiol Biochem 2018;51:1103-1118

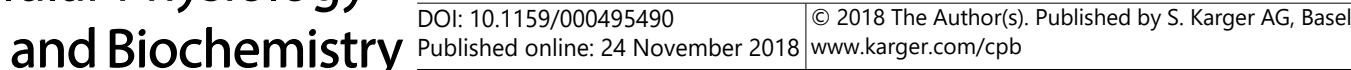 \\ Rentschler et al.: Argonaute 2 in Cytokine-Induced Senescence}

and repression of Ago2-regulated cell cycle control genes. As Ago2 downregulation impairs cytokine-induced growth regulation, Ago2 may contribute to tissue homeostasis in human cancers.

(c) 2018 The Author(s)

Published by S. Karger AG, Basel

\section{Introduction}

Argonaute (Ago) proteins comprise a family of evolutionary conserved proteins that have emerged as key molecules in the control of transcriptional and post-transcriptional processes by association with small RNAs [1]. In humans, the family member Ago2 is a central part of the RNA interference (RNAi) platform with enzymatic endoribonuclease activity [2]. Ago proteins are often recognized by their cytoplasmic function in which they regulate gene transcripts via post-transcriptional gene silencing (PTGS) mechanisms. However, nuclear functions have also been well characterized in fission yeast and plants in which they assist in mechanisms of transcriptional gene silencing (TGS). In fission yeast, Ago binds to antisense transcripts to form the RITS (RNA-induced transcriptional silencing) complex at centromeric regions to induce heterochromatin formation [3]. Thus, Ago proteins normally reside in the cytoplasm, e.g. as part of the RNA-induced silencing complex (RISC), but may eventually translocate into the nucleus and play a functional role in TGS in animal cells, too [4].

Cellular senescence is an efficient intrinsic anticancer mechanism (for reviews see [5, 6]) that stops the growth of premalignant lesions, as in the case of benign human naevi [7] or lung adenomas [8]. Cellular senescence can be triggered by overexpression or activation of oncogenes [9], and the loss of oncogene-induced senescence effectors may lead to the development of malignant tumors [7, 8]. Intrinsic senescence can also be induced by therapeutic intervention, and it has been demonstrated that different antitumor drugs, such as cyclophosphamide [10] or the BRAF inhibitor vemurafenib [11], drive cancer cells into permanent growth arrest. Recently, we and others described cytokine-induced senescence (CIS) as an extrinsic form of senescence. In these studies, adoptive transfer of T helper 1 $\left(\mathrm{T}_{\mathrm{H}} 1\right)$ cells [12] or the application of $\mathrm{T}_{\mathrm{H}} 1$ cell cytokines IFN- $\gamma$ and TNF [12-14] permanently growth-arrested different cancer cells and induced various senescence markers in vitro and in vivo. Thus, CIS can be considered to be a part of the bodies' immune surveillance machinery [15] playing an important role in the equilibrium phase [16] of cancer development. CIS mainly depends on activation of the $\mathrm{p} 16^{\text {Ink4a }} / \mathrm{Rb}$ pathway [12] and consecutive inactivation of the E2F family of transcription factors. However, the exact molecular mechanisms remained enigmatic. As it has been shown that Ago2 plays an active role during intrinsic senescence by corepressing E2F target genes [17], we therefore analyzed its role in CIS. For this, we treated human cancer cell lines with IFN- $\gamma+$ TNF and measured senescence-associated markers, i.e. permanent growth arrest [12] and senescence-associated $\beta$-galactosidase (SA- $\beta$-gal) activity [18]. We then analyzed the expression and nuclear translocation of Ago2 protein after cytokine challenge using Ago2/Ki67 immunofluorescence staining. Finally, we tested its functional role in extrinsic, cytokine-induced growth arrest by analyzing the regulation of Ago2-dependent cell cycle control genes and by siRNA-mediated downregulation of Ago2.

\section{Materials and Methods}

\section{Reagents}

Recombinant human IFN- $\gamma$ and recombinant human TNF were purchased from R \& D Systems (BioTechne GmbH; Wiesbaden, Germany). IFN- $\gamma$ and TNF were dissolved in complete RPMI 1640 medium, containing stable L-glutamine, $10 \%$ fetal calf serum, HEPES buffer (100 mM), non-essential amino acids, sodium pyruvate $(1 \mathrm{mM})$ and penicillin/streptomycin (100 U/ml; all from Biochrom AG, Berlin, Germany) to give final concentrations of $100 \mathrm{ng} / \mathrm{ml}$ for IFN- $\gamma$ or $200 \mathrm{pg} / \mathrm{ml}-10 \mathrm{ng} / \mathrm{ml}$ for TNF. Doxorubicin hydrochloride was dissolved in dimethyl sulfoxide (DMSO; both from Sigma-Aldrich Chemie GmbH, Taufkirchen, Germany) and used at a concentration of $1 \mu \mathrm{M}$. 


\section{Cellular Physiology Cell Physiol Biochem 2018;51:1103-1118

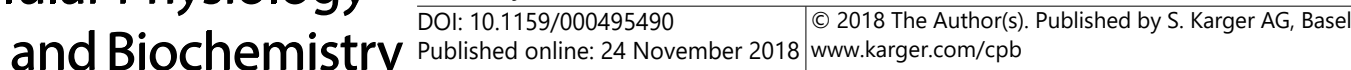 \\ Rentschler et al.: Argonaute 2 in Cytokine-Induced Senescence}

\section{Cell lines}

MCF-7 control vector-transfected breast cancer cells [19] and A204 rhabdomyosarcoma cells [12] were a generous gift by F. Essmann (University of Tübingen, Germany) and K. Schilbach (University of Tübingen, Germany), respectively. Prior to treatment, cells were seeded at a density of $1 \times 10^{4} \mathrm{cells} / \mathrm{cm}^{2}$ and cultured overnight in complete medium to allow adherence and logarithmic growth. Subsequently, medium was removed and cells were either incubated in complete medium alone or in medium containing doxorubicin, IFN- $\gamma+$ TNF, various siRNAs, or IFN- $\gamma+$ TNF in combination with siRNAs at the indicated concentrations and for the indicated time periods.

\section{Viability assay}

Cell viability was determined using the colorimetric XTT (2, 3-bis-(2-methoxy-4-nitro-5-sulfophenyl)2H-tetrazolium-5-carboxanilide) salt-based assay kit from Roche Diagnostics Deutschland GmbH (Mannheim, Germany) according to the manufacturer's instructions.

\section{In vitro growth assay}

The growth assay was performed as described earlier [12]. Briefly, cancer cells were seeded at a density of $1 \times 10^{4}$ cells $/ \mathrm{cm}^{2}$. Then, the cells were treated with control medium, doxorubicin or cytokines as described above for $24 \mathrm{~h}$ or $4 \mathrm{~d}$, respectively. After treatment, medium, doxorubicin or cytokines were removed, the cells were trypsinized, and viable cells (trypan blue exclusion) were counted under a Zeiss Axiovert 25 microscope (Carl Zeiss AG, Oberkochen, Germany) using a Neubauer chamber (Karl Hecht $\mathrm{GmbH}$, Sondheim, Germany). The cells were reseeded at $2 \times 10^{4}$ cells $/ \mathrm{cm}^{2}$, and grown in the absence of doxorubicin or cytokines in complete RPMI 1640 medium for 1 - 2 passages (p (1) - p (2)).

In Ago 2 knockdown experiments, A204 cells were grown to a confluence level of $50-60 \%$ and then treated either with siRNAs, IFN- $\gamma+$ TNF or a combination of siRNAs plus IFN- $\gamma+$ TNF for 48 h. For the growth assay, the number of viable cells was counted after the treatment phase at passage $0(\mathrm{p}(0))$, and after the subsequent passage ( $p(1))$.

To exclude interference of the combined siRNA/cytokine treatment with the trypan blue exclusion assay, we also counted dead cells directly after the treatment phase at $p(0)$ and after further growth at $p$ (1). In the absence of cytokines, siRNA-treated cell populations showed $12.2 \pm 3.5 \%(n=4)$ dead cells at $p(0)$ and $6.2 \pm 1.2 \%(n=4)$ dead cells at $p(1)$, whereas the combination of siRNAs plus cytokines induced $20.2 \pm$ $3.2 \%(n=4)$ dead cells at $p(0)$ and $14.1 \pm 5.3 \%(n=4)$ dead cells at $p(1)$.

\section{Proliferation assay}

For measurement of proliferation, A204 cancer cells were seeded at a density of $5 \times 10^{3}$ cells/well onto 96-well flat-bottomed plates. After $24 \mathrm{~h}$, the cells were either treated with the cytokine cocktail alone, siRNAs alone or a combination of both for the indicated time. In other experiments, the cells were pretreated for $48 \mathrm{~h}$ with siRNAs alone or in combination with the cytokine cocktail. Then, the cells were reseeded to measure the cellular proliferation after removal of the treatment. $\left[{ }^{3} \mathrm{H}\right]$-thymidine $(0.25 \mu \mathrm{Ci} /$ well $)$ was added $24 \mathrm{~h}$ before the respective plates were harvested and finally measured using a FilterMate harvester and a MicroBeta TriLux counter (all reagents and equipment from PerkinElmer, Boston, MA, USA) as previously described [12].

\section{Immunofluorescence}

Cancer cells were grown on chamber slides (BD Biosciences GmbH, Heidelberg, Germany), and immunofluorescence analyses were performed essentially as described [12]. After treatment, the cells were fixed with acetone/methanol (1:1). The slides were washed with PBS/0.05\% Tween 20 at room temperature (RT), blocked with serum-free DAKO-Block (DAKO Deutschland GmbH, Hamburg, Germany), washed again, and incubated with anti-Ki67 (dilution 1:100; Abcam, Cambridge, UK) and anti-Ago2, clone 9E8.2 (dilution 1:200; EMD Millipore, Billerica, MA, USA). After washing, the slides were incubated with antirabbit Alexa488 (Invitrogen; distributed via Thermo Fisher Scientific, Waltham, MA, USA) and anti-mouse Alexa555 (Cell Signaling Technology, Boston, MA, USA), washed again and incubated with 4',6-diamidino2-phenylindole (DAPI; Invitrogen). Finally, the slides were washed, mounted with fluorescence mounting medium (DAKO) and analyzed using a Zeiss Axiovert 200 microscope (Zeiss) with the VisiView software 


\section{Cellular Physiology Cell Physiol Biochem 2018;51:1103-1118

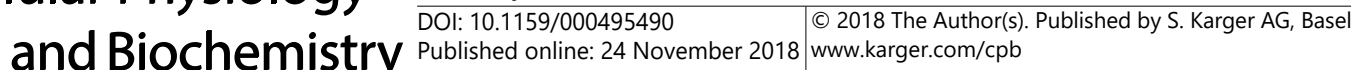 \\ Rentschler et al.: Argonaute 2 in Cytokine-Induced Senescence}

(Visitron Systems, Puchheim, Germany). To exclude unspecific, doxorubicin-mediated fluorescence signals, negative controls (in the absence of anti-Ago2 and anti-Ki67 antibodies) of medium- or doxorubicin-treated cells were performed. At the appropriate device settings, all negative controls were virtually free of red or green fluorescence signals (data not shown).

\section{Subcellular fractionation}

Cell lysis was performed using the NE-PER ${ }^{\mathrm{TM}}$ Nuclear and Cytoplasmic Extraction kit (Thermo Fisher) as described in the manufacturer's protocol.

\section{Immunoblotting}

Western blot analysis was performed essentially as described [20]. After doxorubicin or cytokine treatment, cancer cells were lysed in lysis buffer (50 mM Tris-HCl, pH 7.5, $150 \mathrm{mM} \mathrm{NaCl}, 1 \%$ Triton X-100, $0.5 \% \mathrm{SDS}, 1 \mathrm{mM} \mathrm{NaF}, 1 \mathrm{mM} \mathrm{Na} \mathrm{VO}_{4}$, and $0.4 \% \beta$-mercaptoethanol) containing a protease inhibitor cocktail (cOmplete ${ }^{\mathrm{TM}}$ from Roche). After determination of protein content using the bicinchoninic acid assay (BCA) from Thermo Fisher Scientific or the RotiQuant ${ }^{\mathrm{TM}}$ assay (Carl Roth GmbH + Co. KG, Karlsruhe, Germany), proteins were resolved by SDS-PAGE and transferred onto a polyvinylidene difluoride (PVDF) membrane. Then, specific bands were visualized by the use of anti-Ago2, clone 9E8.2 (1:2000; EMD Millipore), antilamin A/C, clone 131C3 (1:1000; EMD Millipore) or anti- $\beta$-actin monoclonal antibody MAB1501R (1:5000; EMD Millipore) in combination with an anti-mouse horseradish peroxidase (HRP)-conjugated antibody (1:3000; Cell Signaling Technology). Cell lysates from HeLa cells overexpressing Ago2 were used as positive controls (data not shown).

\section{Measurement of SA- $\beta$-galactosidase activity}

SA- $\beta$-gal activity was measured as previously described $[12,18]$. After incubation with doxorubicin, IFN- $\gamma+$ TNF, different siRNAs in combination with IFN- $\gamma+$ TNF, or medium, cancer cells were fixed for $15 \mathrm{~min}$ at RT, and then stained for $16 \mathrm{~h}$ at $37^{\circ} \mathrm{C}$ using the $\beta$-Galactosidase Staining kit (United States Biological; Swampscott, MA, USA). The staining solution was removed, the cells were washed with PBS and subsequently stained with DAPI to allow determination of the total cell number. SA- $\beta$-gal-positive (blue) and -negative (white) cells were counted using a Zeiss Axiovert 200 microscope (Zeiss), and the percentage of SA- $\beta$-gal-positive cells was calculated.

\section{RNA isolation and quantitative PCR}

Isolation of total RNA from cancer cells was performed using the NucleoSpin ${ }^{\circledR}$ RNA Plus kit from Macherey-Nagel (Macherey-Nagel GmbH \& Co. KG, Düren, Germany) according to the manufacturer's protocol. Subsequently, the iScript ${ }^{\mathrm{TM}}$ cDNA synthesis kit (Bio-Rad Laboratories GmbH, Munich, Germany) was used for reverse transcription. Gene expression analysis by quantitative real-time PCR (qPCR) was then conducted essentially as described [12] with a LightCycler ${ }^{\circledR} 480$ II system (Roche) using the following primer pairs in combination with a KAPA SYBR ${ }^{\circledR}$ FAST LC480 qPCR master mix (Sigma-Aldrich):

(i) human PCNA: sense AAGAGAGTGGAGTGGCTTTTG and antisense TGTCGATAAAGAGGAGGAAGC; (ii) human CCNA2: sense CACTCACTGGCTTTTCATCTTC and antisense CAGAAAACCATTGGTCCCTC; (iii) human CCNE2: sense TCTTCACTGCAAGCACCATC and antisense ACCTCATTATTCATTGCTTCCAA; (iv) human CDCA8: sense CTTCGCCCTTGGAGGAAACAA and antisense GGTGTCTGAATAGCTTCTGCTG; (v) human CDC2: sense CATGGCTACCACTTGACCTGT and antisense AAGCCGGGATCTACCATACC; (vi) human AGO2: sense ACTGACAAGAACGAGCG and antisense AGAAACGATTGTCGTCCC; (vii) human ACTB: sense AGCCTCGCCTTTGCCGA and antisense CTGGTGCCTGGGGCG; (viii) human ALDOA: sense GTGTTGTGGGCATCAAGGTAGA and antisense CGAAGTCAGCTCCGTCCTTCT; (ix) human HPRT1: sense TGATAGATCCATTCCTATGACTGTAGA and antisense AAGACATTCTTTCCAGTTAAAGTTGAG. $\beta$-actin, aldolase $A$ and hypoxanthine-guanine phosphoribosyltransferase (HPRT) served as housekeeping genes. For normalization the medium condition or control setting was set as 1 .

Transfection and knockdown of Ago2 by siRNA

For Ago2 knockdown experiments, A204 cells were transfected with 25 nM ON-TARGETplus siRNAs using the DharmaFECT ${ }^{\circledR} 1$ transfection reagent (Dharmacon Inc., Lafayette, CO, USA) according to the supplier's instructions. Specific siRNA duplexes tested included 4 different single Ago2-targeting siRNAs 


\section{Cellular Physiology Cell Physiol Biochem 2018;51:1103-1118 \begin{tabular}{l|l|l} 
and Biochemistry Published onlIne: 24 November 2018 & $\begin{array}{l}\text { (c) } 2018 \text { The Author(s). Published by S. Karger AG, Basel } \\
\text { www.karger.com/cpb }\end{array}$ \\
\hline
\end{tabular}

as well as an Ago2 SMARTpool siRNA. A non-targeting pool was used as control. Functionality of all listed siRNAs was either analyzed in combination with the cytokine cocktail or in culture medium for up to $48 \mathrm{~h}$. After incubation, cancer cells were either used for RNA isolation and immunoblotting to check for knockdown efficiency, or for further in vitro viability, proliferation or senescence assays.

siRNA 1 target sequence: GCACGACUGUGGACACGAA; siRNA 2 target sequence: CCAAGGCGGUCCAGGUUCA; siRNA 3 target sequence: GGUCUAAAGGUGGAGAUAA; siRNA 4 target sequence: CAAGCAGGCCUUCGCACUA; SMARTpool target sequences: GCACGACUGUGGACACGAA, CCAAGGCGGUCCAGGUUCA， GGUCUAAAGGUGGAGAUAA， CAAGCAGGCCUUCGCACUA; Non-targeting pool sequences: UGGUUUACAUGUCGACUAA, UGGUUUACAUGUUGUGUGA, UGGUUUACAUGUUUUCUGA, UGGUUUACAUGUUUUCCUA.

\section{Statistics}

Data are expressed as arithmetic means \pm s.e.m. (technical replicates), and statistical analyses were made by unpaired t-test, or ANOVA using Dunnett's or Tukey's test as post hoc test, where appropriate. $\mathrm{P}<0.05$ was considered statistically different. Experiments were performed in two human cancer cell lines (MCF-7 and A204; biological replicates).

\section{Results}

Nuclear translocation of Ago2 during doxorubicin-induced senescence

First, we established the methods to analyze the role of Ago 2 in cellular senescence. MCF7 breast cancer cells were treated with $1 \mu \mathrm{M}$ doxorubicin for $24 \mathrm{~h}$ followed by removal of the drug for $96 \mathrm{~h}$ essentially as described previously [17]. As expected, doxorubicin treatment of the apoptosis-refractory MCF-7 cell line [19] inhibited the proliferation of the cancer cells. Most importantly, doxorubicin also stopped MCF-7 cell growth for 2 passages after removal of the drug (Fig. 1A). In addition, doxorubicin induced a flat, senescence-like cell morphology (Fig. 1B), increased senescence-associated $\beta$-galactosidase (SA- $\beta$-gal)-positive cells to approximately $80 \%$ (Fig. 1C), and blunted BrdU incorporation into the DNA of proliferating cells by $>95 \%$ (Fig. 1D). Next, we analyzed Ago2 translocation into the nucleus during druginduced senescence. Immunofluorescence analysis indeed showed translocation of Ago2 into the nucleus of non-proliferating, Ki67-negative MCF-7 cells after doxorubicin treatment (Fig. 1E, F). Importantly, Ago2 translocation could also be demonstrated by western blot analysis of nuclear extracts of doxorubicin-treated MCF-7 cells. As compared with mediumtreated control cells, the ratio of nuclear to cytoplasmic Ago2 was clearly increased after doxorubicin treatment (Fig. 1G). Thus, the methods described above are well suited to analyze Ago2 translocation during cytokine-induced senescence (CIS).

\section{Nuclear translocation of Ago2 during cytokine-induced senescence}

The combined action of interferon- $\gamma$ (IFN- $\gamma$ ) and tumor necrosis factor (TNF) drives various cancer cells into senescence [12-14]. We therefore treated MCF-7 cells with the established cytokine cocktail for $96 \mathrm{~h}$, and then analyzed different senescence-associated markers. Indeed, IFN- $\gamma+$ TNF permanently stopped the proliferation of MCF-7 cells, also after cytokine removal (Fig. 2A), and induced the typical egg-shaped, senescence-like morphology and SA- $\beta$-gal activity (Fig. 2B). As in the case of drug-induced senescence, Ago2 translocated into the nucleus of IFN- $\gamma+$ TNF-treated MCF-7 cells (Fig. 2C) thereby increasing Ago2 ${ }^{+} / \mathrm{Ki}^{-}$cells from $10 \%$ to $77 \%$ (Fig. 2D). Cytokine-induced translocation of Ago2 into the nucleus of MCF-7 cells was verified by western blot analysis of nuclear extracts (Fig. 2E). Further experiments using the cytokine-sensitive rhabdomyosarcoma cell line A204 [12, 13] demonstrated that IFN- $\gamma+$ TNF also induced the flat senescence-associated morphology (Fig. 2F), increased SA- $\beta$-gal activity (Fig. 2F), and enhanced nuclear translocation of Ago2 in those cells (Fig. 2G, H). These data clearly demonstrate that nuclear Ago2 translocation occurs during CIS in two different cancer cell lines. 


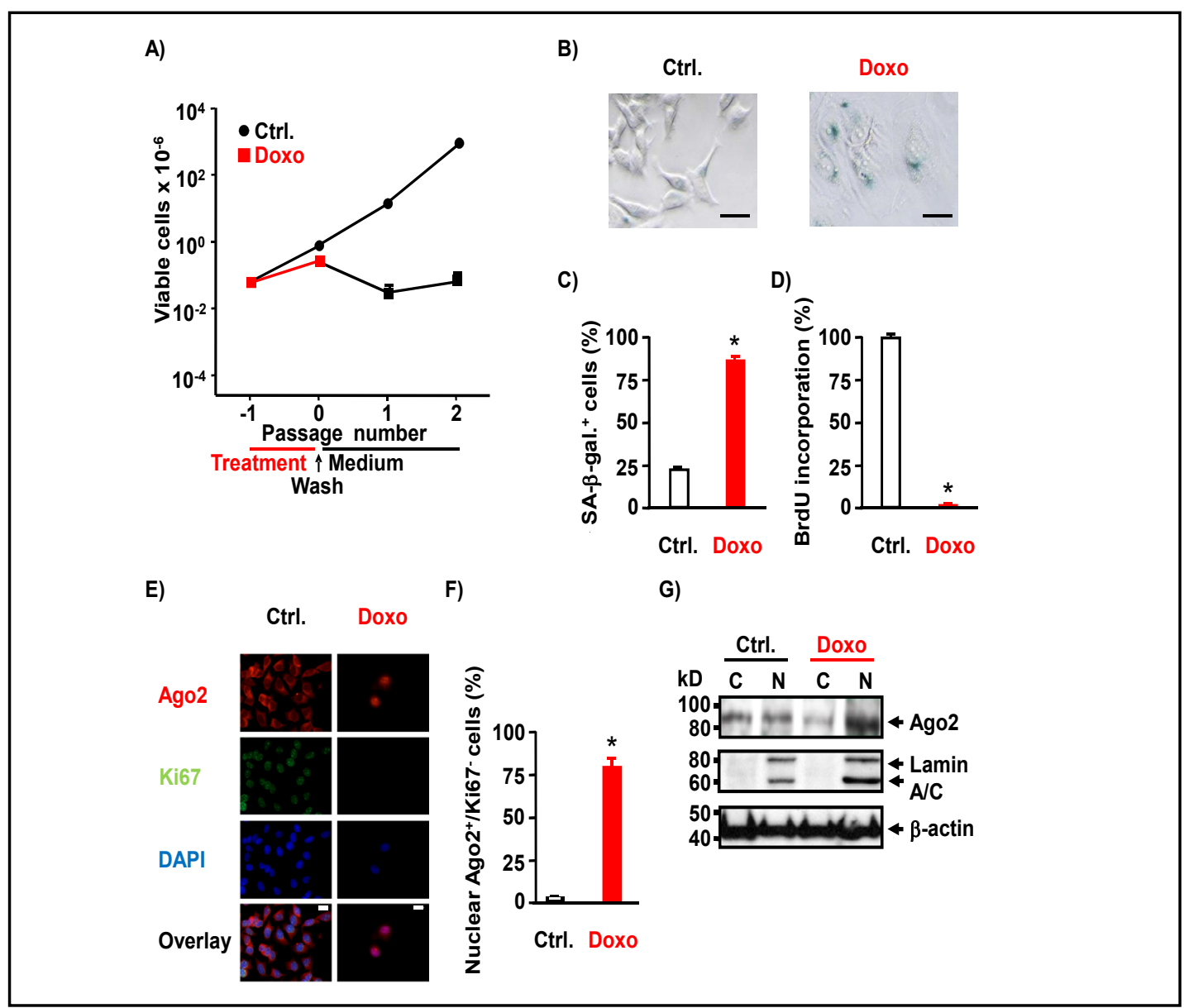

Fig. 1. Doxorubicin induces growth arrest, $S A-\beta$-galactosidase activity, inhibition of BrdU incorporation and nuclear Ago2 translocation in MCF-7 cells. A) MCF-7 breast cancer cells were treated for $24 \mathrm{~h}$ with medium (Ctrl.) or with medium containing $1 \mu \mathrm{M}$ doxorubicin (Doxo). The cytostatic drug was removed, cells were trypsinized, counted, and seeded at $2 \times 10^{4}$ cells/well. The cells were grown for $96 \mathrm{~h}$ in medium alone, trypsinized and reseeded for two further passages ( $p(1)-p(2))$. Cell counts are represented as mean \pm s.e.m. (n=4). B-D) Alternatively, SA- $\beta$-gal staining (B, C) or a BrdU incorporation assay (D) was performed 96 $\mathrm{h}$ after drug removal, and the percentage of SA- $\beta$-gal ${ }^{+}$cells (C; mean \pm s.e.m., $\mathrm{n}=5$ ) or BrdU incorporation (D; mean \pm s.e.m., $n=12$ ) is given. E, F) In addition, nuclear Ago2 translocation after $24 \mathrm{~h}$ drug treatment and 96 $\mathrm{h}$ drug removal is shown by immunofluorescence staining for Ago2 (red) and Ki67 (green), nuclei appear in blue (E), and the percentage of nuclear Ago $2^{+} /$Ki67 cells is given (F; mean \pm s.e.m., $n=12$ for Ctrl., $n=20$ for Doxo). (G) Ago2, lamin A/C, or $\beta$-actin in cytosolic (C) or nuclear (N) extracts as detected by western blotting in MCF-7 cells treated with medium (Ctrl.) or doxorubicin (Doxo) are shown $96 \mathrm{~h}$ after removal of the drug. Bar $=25 \mu \mathrm{m}(\mathrm{B})$ or $10 \mu \mathrm{m}(\mathrm{E}) .{ }^{*} \mathrm{P}<0.05$ from medium-treated control (C, D, F).

\section{Kinetics of Ago2 translocation after cytokine treatment}

IFN- $\gamma+$ TNF-induced senescence is an extrinsic senescence pathway that has been shown to be TNF receptor 1 (TNFR1)- and signal transducer and activator of transcription 1 (STAT1)dependent [12]. After simultaneous stimulation of the cytokine receptors, senescence signaling via two converging signaling pathways takes place [21]. In this setting, complete senescence induction takes about 4 to 5 days [12]. To disclose the kinetics of senescence induction and Ago 2 translocation in more detail, we treated A204 or MCF-7 cells with IFN- $\gamma+$ TNF for $24-72 \mathrm{~h}$, and measured SA- $\beta$-gal activity and Ago 2 translocation in parallel (Fig. 3AD). In A204 cells (Fig. 3A) as well as in MCF-7 cells (Fig. 3C), the percentage of SA- $\beta$-gal ${ }^{+}$cells steadily increased as compared with medium-treated controls during the whole incubation KARGER 


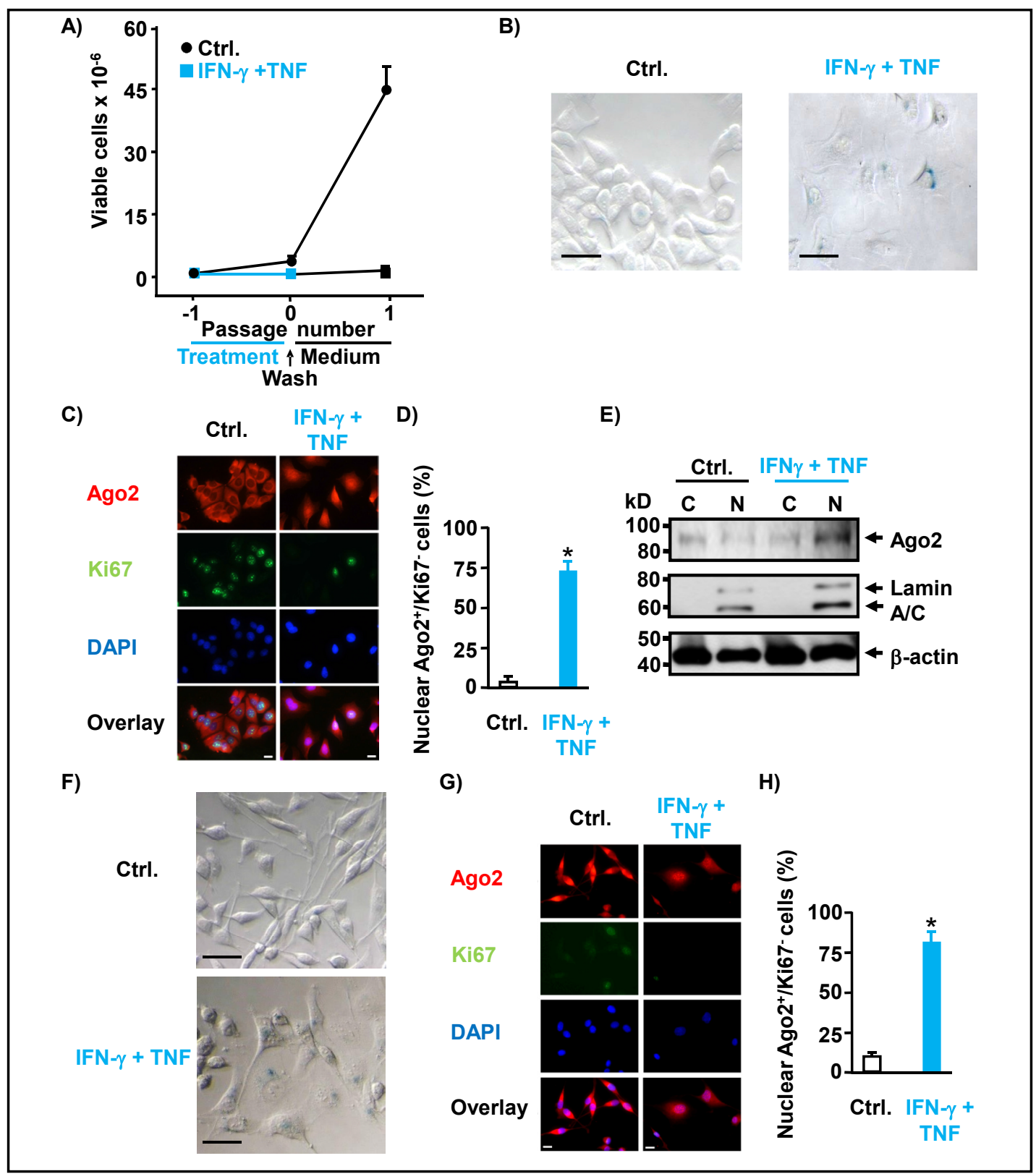

Fig. 2. IFN- $\gamma$ and TNF induce senescence and nuclear Ago2 translocation in human cancer cells. A) MCF-7 breast cancer cells were treated for $96 \mathrm{~h}$ with medium (Ctrl.) or with medium containing $100 \mathrm{ng} / \mathrm{ml} \mathrm{IFN- \gamma}$ and $10 \mathrm{ng} / \mathrm{ml}$ TNF (IFN- $\gamma+$ TNF). The cytokines were removed, cells were trypsinized, reseeded at $1.5 \times 10^{4}$ cells/well and grown for one additional passage ( $\mathrm{p}(1)$ ) in medium alone. After $96 \mathrm{~h}$ of cytokine removal, cells were trypsinized and counted. Cell counts are represented as mean \pm s.e.m. $(n=4)$. B) SA- $\beta$-gal staining of MCF-7 cells after $72 \mathrm{~h}$ of IFN- $\gamma+$ TNF treatment. Note the flat senescence-associated morphology of cytokine-treated cells. C, D) Immunofluorescence staining for Ago2 (red), Ki67 (green) or DAPI (blue) (C) and percentage of nuclear Ago2 ${ }^{+} /$Ki67 cells (D; mean \pm s.e.m., $n=7$ ) after 48 h of IFN- $\gamma+$ TNF treatment. E) Ago2, lamin $\mathrm{A} / \mathrm{C}$, or $\beta$-actin in cytosolic $(\mathrm{C})$ or nuclear $(\mathrm{N})$ extracts as detected by western blotting in MCF-7 cells treated with medium (Ctrl.) or IFN- $\gamma+$ TNF are shown after $72 \mathrm{~h}$ of treatment. F) SA- $\beta$-gal activity staining of A204 rhabdomyosarcoma cells after $72 \mathrm{~h}$ of treatment with $100 \mathrm{ng} / \mathrm{ml} \mathrm{IFN}-\gamma+400 \mathrm{pg} / \mathrm{ml}$ TNF. Note the flat senescence-associated morphology of cytokine-treated cells. G, H) Immunofluorescence staining for Ago2 (red), Ki67 (green) or DAPI (blue) (G) and percentage of nuclear Ago $2^{+} / \mathrm{Ki}^{-}$cells $(\mathrm{H}$; mean \pm s.e.m., $n=6$ for Ctrl. or $n=8$ for IFN- $\gamma+$ TNF) after $72 \mathrm{~h}$ of IFN- $\gamma+$ TNF treatment. Bar $=25 \mu \mathrm{m}(\mathrm{B}, \mathrm{F})$, or $10 \mu \mathrm{m}(\mathrm{C}, \mathrm{G}) .{ }^{*} \mathrm{P}<0.05$ from medium-treated control $(\mathrm{D}, \mathrm{H})$. 
time of $72 \mathrm{~h}$ thereby indicating that senescence induction continuously proceeds after start of the cytokine treatment. On the other hand, $20 \%$ or $50 \%$ of the total cell population already showed nuclear Ago2 translocation after $24 \mathrm{~h}$ of treatment in A204 or MCF7 cells, respectively (Fig. 3B, D). In these experiments, Ago2 translocation reached a peak of $65 \%$ (A204) or $74 \%$ (MCF-7) after $48 \mathrm{~h}$ of treatment with the cytokine cocktail (Fig. 3B, D). Thus, Ago2 translocation into the nucleus appears as an early event in the signaling pathway of CIS and does not simply represent another senescence marker of permanently arrested cancer cells.

Ago2 translocation after cytokine challenge is reversible

Higher magnification of the immunofluorescence pictures revealed that Ago2 is present in three cellular compartments. Besides its cytoplasmic and nuclear localization, we also detected Ago2 in the perinuclear region of cytokine-treated A204 cells (Fig. 4A). We therefore reasoned that Ago2 might shuttle between the cytosol and the nucleus of the cells. To study this in more detail, we treated cells for $72 \mathrm{~h}$ with IFN- $\gamma+$ TNF, then removed the cytokines, and incubated the cells for another $48 \mathrm{~h}$ or $120 \mathrm{~h}$ in the absence of the stressors. Again, Ago 2 accumulated in the nucleus of Ki67-negative A204 cells after $72 \mathrm{~h}$ of cytokine treatment (Fig. 4B). $48 \mathrm{~h}$ after cytokine removal, the percentage of Ago2 $/ \mathrm{Ki} 67^{-}$cells already declined, and nearly reached control levels another $72 \mathrm{~h}$ later (Fig. 4B). Taken together, Ago 2 rapidly translocates into the nucleus after stimulation of the cytokine receptors, and the protein reenters the cytosol when cytokine signaling is terminated.

Suppression of Ago2-regulated cell cycle control genes during cytokine-induced senescence

Ago2 has been described as a corepressor of several cell cycle genes thereby interfering with enhanced cell proliferation [17]. We thus measured the time-dependent influence of IFN- $\gamma+$ TNF on the expression of known Ago2-regulated cell cycle control genes in A204 cells. $24 \mathrm{~h}$ of cytokine treatment, a time point where Ago 2 is already present in the nucleus, reduced the expression of proliferating cell nuclear antigen (PCNA), cyclin A2 (CCNA2), cyclin E2 (CCNE2), cell division cycle associated 8 (CDCA8), and cell division control protein 2 (CDC2; also known as cyclin-dependent kinase 1 (CDK1)) by $25-50 \%$ (Fig. 5A). With the exception of PCNA, suppression of the cell cycle control genes was continuing for the whole period of $96 \mathrm{~h}$ of sustained cytokine treatment and did not resume the starting levels at time point 0 (Fig. 5A). Further experiments with A204 rhabdomyosarcoma (blue dots) or MCF-7 


\section{Cellular Physiology Cell Physiol Biochem 2018;51:1103-1118

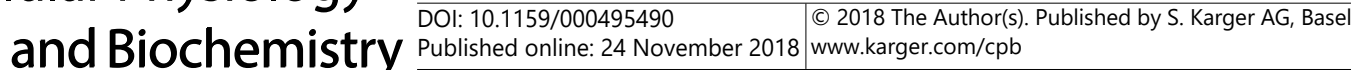 \\ Rentschler et al.: Argonaute 2 in Cytokine-Induced Senescence}

breast cancer cells (red dots) confirmed the downregulation of all five cell cycle genes after $24 \mathrm{~h}$ and $48 \mathrm{~h}$ (Fig. 5B). Thus, CIS proceeds through rapid suppression of 5 important cell cycle control genes which are known to be regulated by Ago2.

Transient downregulation of Ago2 by siRNA impairs cytokine-induced cell growth inhibition

To examine the functional role of Ago 2 in cell cycle regulation in more detail, we downregulated Ago2 in A204 cells using siRNAs. Combined treatment of siRNAs with cytokines for $72 \mathrm{~h}$ strongly impacted the viability of cells in an Ago2independent manner. The number of viable cells was $14.9 \pm 1.9 \%(n=6)$ for Ago2 siRNA plus cytokine-treated cells and $17.0 \pm 1.2 \%(\mathrm{n}=6)$ for non-targeting control siRNA plus cytokine-treated cells as compared with transfection reagenttreated cells. We therefore reduced the siRNA treatment cycles to $24 \mathrm{~h}-48 \mathrm{~h}$ in the absence (Fig. 6A) or presence of IFN- $\gamma$ + TNF (Fig. 6B). We could demonstrate that a mixture of four different Ago2 siRNAs (SMARTpool) as well as single Ago2-specific siRNAs reduced Ago2 mRNA levels by $70 \%-80 \%$ as compared

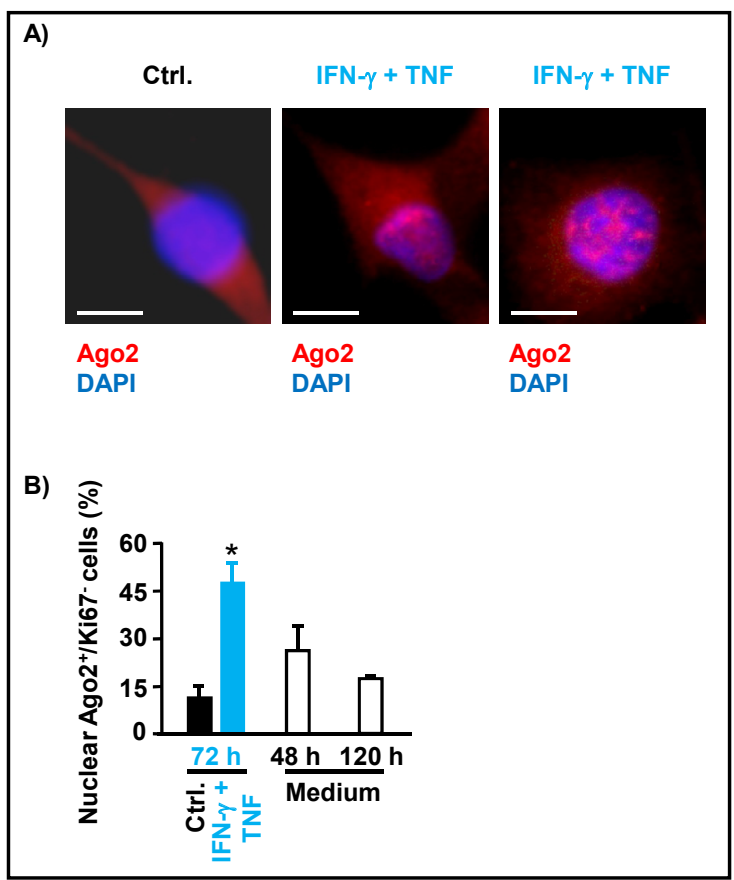

Fig. 4. Ago 2 shuttling between the nucleus and cytosol. A) Localization of Ago2 (red) in the cytosol of medium-treated A204 cells (left), in the perinuclear region (middle) or in the nucleus (right) of IFN- $\gamma$ + TNF-treated A204 cells. Nuclei appear in blue. B) Retranslocation of Ago2 into the cytosol after cytokine removal in A204 cells (mean \pm s.e.m., $n=3-6$ ). Bar $=10$ $\mu \mathrm{m}(\mathrm{A}) .{ }^{*} \mathrm{P}<0.05$ from medium-treated control (B). with control siRNAs (non-targeting pool)

(Fig. 6C), while the viability of Ago2 siRNA-treated cells was only slightly reduced $(82.4 \pm$ $1.2 \%(n=6)$ as compared with siCtrl.). Additionally, specific siRNAs also downregulated Ago2 expression in the presence of the cytokine cocktail (Fig. 6C) without significantly influencing the viability ( $105.3 \pm 9.7 \%(n=6)$ as compared with siCtrl.). Transient knockdown of Ago2 was also confirmed on the protein level (Fig. 6D). Next, we tested the functional effects of Ago2 downregulation, and measured the proliferation of A204 cells by $\left[{ }^{3} \mathrm{H}\right]$-thymidine incorporation. IFN- $\gamma+$ TNF blunted proliferation of A204 cells already after $24 \mathrm{~h}$. The inhibition lasted at least $96 \mathrm{~h}$ (Fig. 7A). Then, we asked whether Ago2- siRNAs could antagonize the cytokine-induced inhibition of proliferation. However, we realized that siRNA treatment in the absence of cytokines strongly reduced $\left[{ }^{3} \mathrm{H}\right]$-thymidine incorporation to a similar level (Fig. 7B). Thus, analysis of cell proliferation by this method did not show consistent effects of Ago2 knockdown on cytokine-induced inhibition of DNA synthesis, neither during the 48 $\mathrm{h}$ treatment phase (Fig. 7B) nor after removal of the stressors (Fig. 7C). Subsequently, we

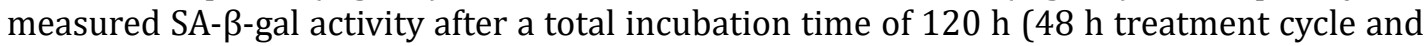
$72 \mathrm{~h}$ removal phase). After this long incubation time, the medium-treated, siAgo2- or siCtrl.transfected cells already showed high levels of SA- $\beta$-gal ${ }^{+}$cells (Fig. 7D). Nevertheless, siCtrl.treated A204 cells still responded to IFN $-\gamma+$ TNF, and the cytokine cocktail significantly increased the percentage of SA- $\beta$-gal ${ }^{+}$cells up to approximately $86 \%$. In contrast, the cytokine cocktail failed to further enhance SA- $\beta$-gal activity in siAgo2-treated A204 cells (Fig. 7D). To functionally test for another feature of senescent cells, i.e. cell cycle arrest, we performed established growth assays [12] with some modifications (see also Material and Methods). In the absence of cytokines, siAgo treatment did not change the proliferative behavior of A204 cells after one $48 \mathrm{~h}$ treatment cycle (Fig. 7E, F). In contrast, Ago2-specific siRNAs changed 
Fig. 5. Repression of Ago2-regulated cell cycle control genes after cytokine treatment of cancer cells. A) Expression of cell cycle control genes in A204 cells after 24 h, 48 h or 96 h of IFN- $\gamma$ + TNF. Relative gene expression of A204 cells was assayed in duplicates and time point $0 \mathrm{~h}$ was set as 1. The experiment was repeated with similar results. B) Gene expression of A204 cells (blue dots) or MCF-7 cells (red dots) after treatment with IFN- $\gamma+$ TNF for 24 h (left) or 48 h (right) was assayed in duplicates. Data are given as \% difference from medium-treated controls. The black bars indicate the mean value of gene downregulation of the respective cell cycle control genes. CCNA2, cyclin A2; CCNE2, cyclin E2; CDCA8, cell division cycle associated 8; CDC2, cell division control protein 2; PCNA, proliferating cell nuclear antigen.

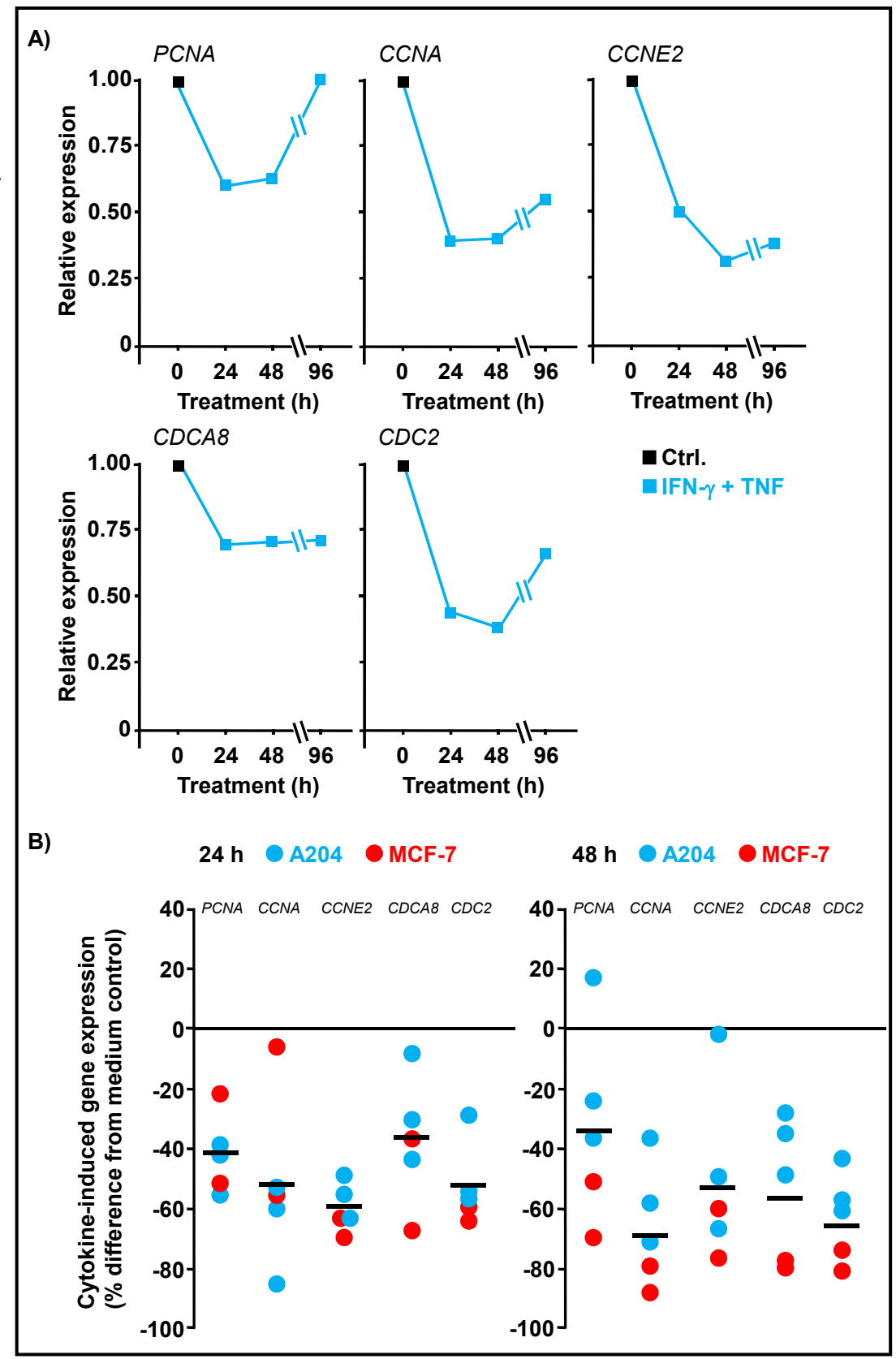

the growth characteristics of cytokine-treated A204 cells when compared with Ctrl. siRNAs (Fig. 7G). Ago2 downregulation repeatedly led to an increase of the relative growth rate as in comparison with the Ctrl. siRNAs (Fig. 7H). Taken together, these data support the notion that Ago 2 interferes with IFN- $\gamma+$ TNF-induced growth inhibition during the first $48 \mathrm{~h}$ of cytokine treatment. 


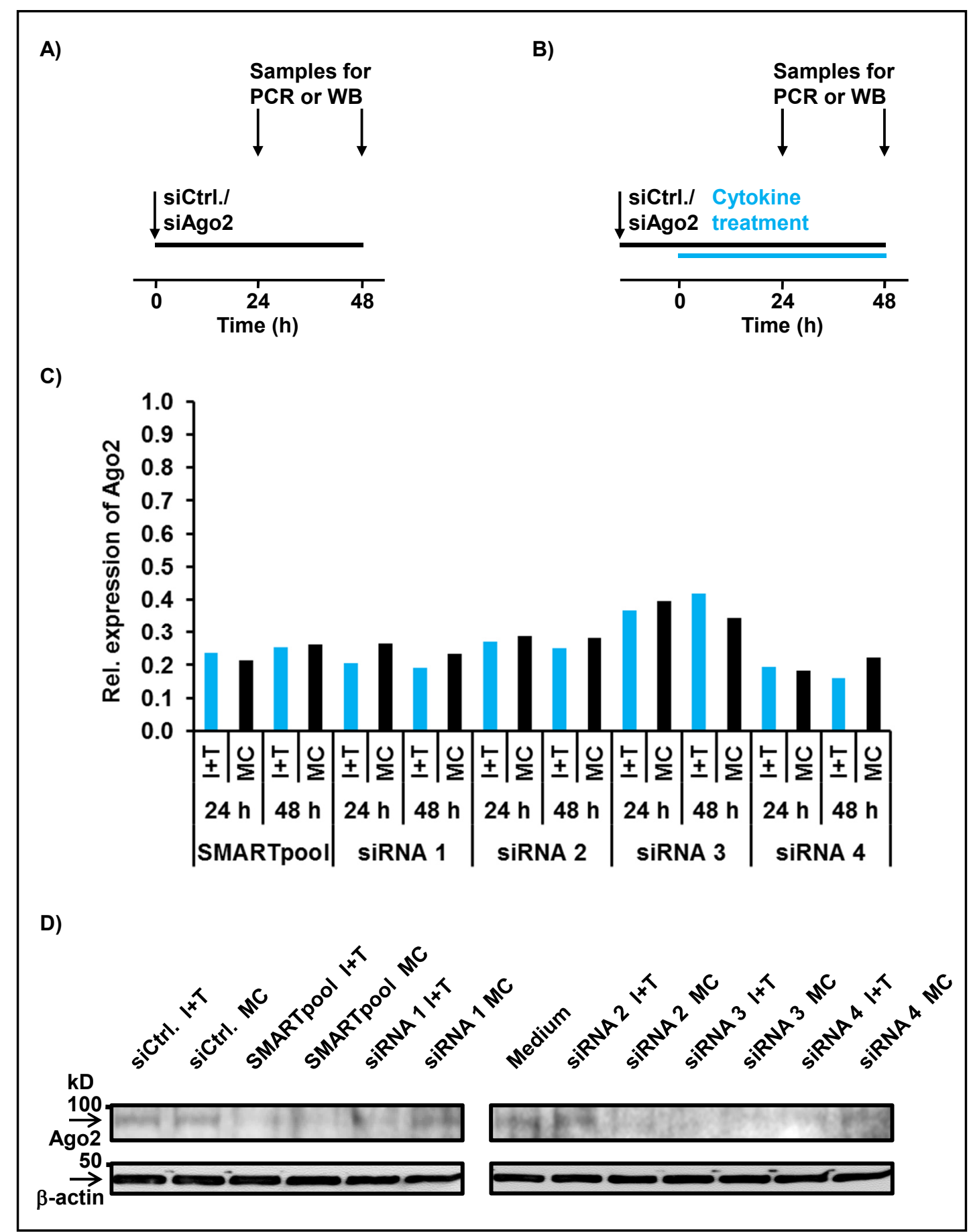

Fig. 6. Knockdown of Ago 2 in A204 cells by the use of siRNA. A, B) Experimental set up for transient, siRNAmediated downregulation of Ago2 either in the absence (A) or presence of IFN- $\gamma+$ TNF (B). C) Knockdown of Ago2 expression by SMARTpool Ago2-siRNA or by single Ago2-specific siRNAs as measured by qPCR after $24 \mathrm{~h}$ or $48 \mathrm{~h}$ of incubation. Ago2 expression of non-targeting siRNA controls was set as 1. Data are presented as relative expression (mean of two determinations, each). D) Downregulation of Ago 2 protein levels by SMARTpool Ago2-siRNA or by single Ago2-specific siRNAs as determined by western blot after 48 h of incubation. 
Fig. 7. Influence of Ago2 knockdown on INF- $\gamma$ and TNF mediated growth behavior of A204 cells. A) Proliferation of cytokine-treated (blue bars) or medium-treated (black bars) A204 cells as measured by $\left[{ }^{3} \mathrm{H}\right]$-thymidine i n corporation (mean \pm s.e.m., $\mathrm{n}=6)$. B) A204 cells were treated with Ago2- or Ctrl.-siRNAs either in the absence (closed black bars) or presence (closed blue bars) of IFN- $\gamma+$ TNF. Simultaneously, A204 cells were also incubated without siRNAs in medium alone (open black bar) or with the cytokine cocktail (open blue bar). After $48 \mathrm{~h}$ of incubation, cellular proliferation was assessed by the

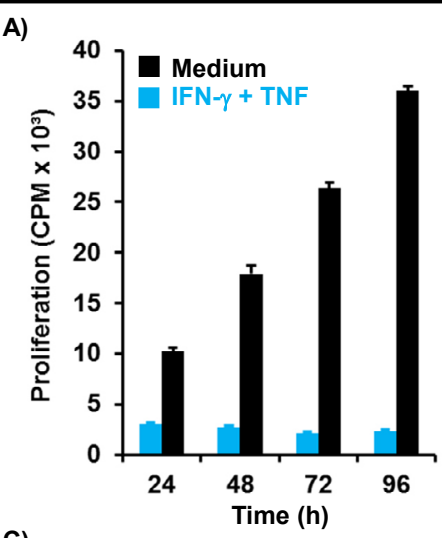

C)

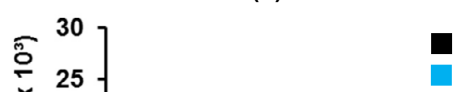

Medium IFN- $\gamma+$ TNF

D)

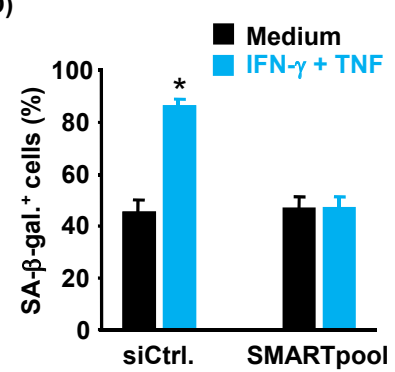

uptake of $\left[{ }^{3} \mathrm{H}\right]-$

thymidine (mean \pm s.e.m., $\mathrm{n}=6$ ). C) After $48 \mathrm{~h}$ treatment with Ago2- or Ctrl.-siRNAs, either in the absence (closed black bars) or presence (closed blue bars) of IFN- $\gamma+$ TNF, A20 4 cells were reseeded without the stressors to analyze their proliferative capacity during the following $72 \mathrm{~h}$ using $\left[{ }^{3} \mathrm{H}\right]$-thymidine. Additionally, the growth behavior of A204 cells preincubated for $48 \mathrm{~h}$ without siRNAs in medium alone (open black bar) or with the cytokine cocktail (open blue bar) was also measured $72 \mathrm{~h}$ after reseeding (mean \pm s.e.m., $\mathrm{n}=6$ ). D) A204 cells were treated with Crtl-siRNA (left) or SMARTpool Ago2-siRNA (right) for $48 \mathrm{~h}$, either in the absence (medium) or presence of IFN- $\gamma+$ TNF. $72 \mathrm{~h}$ after removal of the siRNAs and cytokines, SA- $\beta$-gal activity was measured (mean \pm s.e.m., $\mathrm{n}=6$ ). ${ }^{*} \mathrm{P}<0.05$ from medium-treated control. E, F) Growth curves of Ctrl--siRNA- (open diamonds) or Ago2-siRNA-treated A204 cells (closed dots) in the absence of IFN- $\gamma$ + TNF for $48 \mathrm{~h}(\mathrm{E})$, and relative growth of siAgo2-treated cells at $\mathrm{p}(1)$ after removal of the siRNAs (n=7). Cellular growth of non-targeting siRNA controls were set as 1 (F). G, H) Growth curves of Ctrl.-siRNA- (open diamonds) or Ago2-siRNA-treated A204 cells (closed dots) in the presence of IFN- $\gamma+$ TNF for $48 \mathrm{~h}(\mathrm{G})$, and relative growth of siAgo2-treated cells at $p(1)$ after removal of the stressors (n=7). Cellular growth of nontargeting siRNA controls was set as $1(\mathrm{H})$. CPM = counts per minute (A-C). siCtrl.=non-targeting pool siRNA; siAgo2=Ago2 SMARTpool siRNA $(\mathrm{A}-\mathrm{H})$. 


\section{Cellular Physiology Cell Physiol Biochem 2018;51:1103-1118

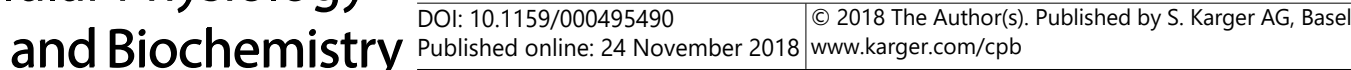 \\ Rentschler et al.: Argonaute 2 in Cytokine-Induced Senescence}

\section{Discussion}

Ago 2 is a prominent member of the argonaute protein family. The protein combines RNA binding properties with an intrinsic enzyme activity and is thus a central part of the RNA silencing machinery [2]. Besides its role as the enzymatic component of the cytosolic RISC, translocation of Ago2 into the nucleus has been described [17, 22]. In addition, detailed analysis of the subcellular localization of Ago2 revealed that the protein also associates physically with the rough endoplasmic reticulum [23]. This fits well with our high resolution immunofluorescence pictures showing a perinuclear localization of Ago2, and with our observation that Ago2 may shuttle between the cytosol and the nucleus. Whereas the molecular regulation of Ago2 as part of the RISC or as part of the nuclear gene silencing machinery has been extensively studied, not that much is known about the roles of Ago2 in superordinated cellular processes, such as apoptosis, differentiation, proliferation or permanent growth arrest. For example, it has been demonstrated that the activity of Ago2 is regulated by phosphorylation/dephosphorylation [24-26]. These data clearly show that (i) an Ago2 phosphorylation cycle regulates the interactions of miRNAs with their targets [26], (ii) the epidermal growth factor receptor (EGFR) enhances Ago2 phosphorylation which in turn inhibits miRNA processing [24] and (iii) phosphorylation of Ago2 at the amino acid residue Tyr 393 inhibits loading with miRNAs and miRNA-mediated gene silencing [25]. According to these data, phosphorylation of Ago 2 correlates with a disturbed function as a gene silencer. In this line, preliminary data from our laboratory show that cytokine treatment of cancer cells leads to a rapid dephosphorylation of Ago2 thereby pointing to activation of its gene silencing function (data not shown).

As far as the role of Ago proteins in essential cellular pathways is concerned, several reports point to Ago-dependent regulation of programmed cell death or apoptosis [27-29]. For example, evidence has been provided that Ago2/miR-21 targets large tumor suppressor kinase 1 (LATS1) thereby inhibiting apoptosis in T cells [29]. This miRNA-mediated mechanism might explain the involvement of Ago 2 in this process, as apoptosis is a rapidly proceeding cellular pathway with activation of the executioner enzymes, i.e. caspases, as early as $10 \mathrm{~h}$ to $48 \mathrm{~h}$ after challenge with the death-inducing substances [30,31]. In addition, Ago2 downregulation has been associated with apoptosis induction in prostate cancer cells [28]. Thus, Ago2 seems to counteract apoptosis. On the other hand, as demonstrated in the present study for extrinsic, cytokine-induced growth inhibition, and by others for intrinsic, oncogene-induced senescence $[17,25]$, Ago2 nuclear translocation favors growth arrest. This is an interesting aspect as it is known that senescent cells are resistant to stimulusspecific apoptosis induction [32], but can be specifically cleared by targeted apoptosis induction using proapoptotic FOXO4-derived peptides [33].

Senescence induction in tumors is an intrinsic cellular response to oncogenic signaling that may have evolved alongside apoptosis to suppress tumorigenesis [34]. However, in contrast to apoptosis, senescent cells are viable over a long period of time. In addition, they have the potential to influence neighboring tumor cells or cells of the tumor microenvironment through secreted soluble molecules, known as the senescence-associated secretory phenotype (SASP) [35-37]. Interestingly, the transcellular regulation of senescence by soluble factors is also true vice versa: our findings that specific immune cells control cancer cells by cytokine secretion and CIS [12] demonstrate that immune surveillance of tumors $[16,38]$ takes advantage of extrinsic, receptor-mediated senescence pathways. CIS is now accepted as a non-cell-autonomous inducer of cellular senescence that limits tumorigenesis [15], and several different cytokines or cytokine mixtures, e.g. interleukin-6 (IL-6) [39], transforming growth factor beta (TGF- $\beta$ ) [40], or IFN- $\gamma$ and TNF [12-14], have been implicated in senescence induction. 


\section{Cellular Physiology Cell Physiol Biochem 2018;51:1103-1118 and Biochemistry \begin{tabular}{l|l} 
DOI: 10.1159/000495490 & $\begin{array}{l}\text { (c) } 2018 \text { The Author(s). Published by S. Karger AG, Basel } \\
\text { www.karger.com/cpb }\end{array}$
\end{tabular} \\ Rentschler et al.: Argonaute 2 in Cytokine-Induced Senescence}

\section{Conclusion}

In conclusion, we show here that the small RNA-binding protein Ago2 rapidly translocates into the nucleus of senescence-prone cancer cells after stimulation with the $\mathrm{T}_{H} 1$ cell cytokines IFN- $\gamma$ and TNF. Ago 2 translocation in cancer cells is already observed after $24 \mathrm{~h}$ and reached a maximum after $48 \mathrm{~h}$ of treatment thereby preceding the induction of permanent growth arrest which takes at least $96 \mathrm{~h}$ continuous presence of IFN- $\gamma$ and TNF [12]. We also show the suppression of important Ago2-regulated cell cycle control genes as early as $24 \mathrm{~h}$ after cytokine challenge thereby pointing to a functional role of Ago2 in the signal transduction of CIS. In addition, the role of Ago 2 during the first $48 \mathrm{~h}$ of cytokine treatment was supported by transient Ago2 downregulation, and subsequent measurement of the senescence marker SA$\beta$-gal [18] and the growth characteristics of the cells. Future studies will aim to decipher (i) the signals that mediate Ago 2 translocation in CIS, e.g. phosphorylation/dephosphorylation and binding to nuclear import proteins, (ii) the binding partners of Ago2 which build up the repressor complex that leads to transcriptional silencing of the important cell cycle control genes in CIS and (iii) the role of Ago2 in the later phases of CIS, i.e. in the phase of permanent growth arrest which, at least in vitro, may last several weeks.

\section{Acknowledgements}

Martin Röcken and Thomas Wieder share senior authorship. The authors would like to thank S. Weidemann and V. Galinat for expert technical assistance. This work was supported by the Wilhelm Sander Foundation (2012.056.3 to M.R.), German Cancer Aid (application numbers 109037 and 110664 to M.R.), and German Research Association (TRR-SFB 156, DFG RO 764/14-1 and DFG R0 764/15-2 to M.R. and DFG WI 1279/4-1 to T.W.). The group of O.B. is supported by grants from ANR-BMFT, Fondation ARC pour la recherche sur le Cancer, INSERM, and the National Cancer Institute of the National Institutes of Health under Award Number R01CA136533. O.B. is a CNRS Research Director DR2.

We acknowledge support by Deutsche Forschungsgemeinschaft and open Access Publishing Fund of University of Tübingen.

\section{Disclosure Statement}

No conflicts of interest, financial or otherwise, are declared by the authors.

\section{References}

1 Farazi TA, Juranek SA, Tuschl T: The growing catalog of small RNAs and their association with distinct Argonaute/Piwi family members. Development 2008;135:1201-1214.

-2 Meister G, Landthaler M, Patkaniowska A, Dorsett Y, Teng G, Tuschl T: Human Argonaute2 mediates RNA cleavage targeted by miRNAs and siRNAs. Mol Cell 2004;15:185-197.

-3 Castel SE, Martienssen RA: RNA interference in the nucleus: roles for small RNAs in transcription, epigenetics and beyond. Nat Rev Genet 2013;14:100-112.

4 Buckley BA, Burkhart KB, Gu SG, Spracklin G, Kershner A, Fritz H, Kimble J, Fire A, Kennedy S: A nuclear Argonaute promotes multigenerational epigenetic inheritance and germline immortality. Nature 2012;489:447-451.

5 Pérez-Mancera PA, Young AR, Narita M: Inside and out: the activities of senescence in cancer. Nat Rev Cancer 2014;14:547-558.

-6 Muñoz-Espín D, Serrano M: Cellular senescence: from physiology to pathology. Nat Rev Mol Cell Biol 2014;15:482-496. 


\section{Cellular Physiology Cell Physiol Biochem 2018;51:1103-1118

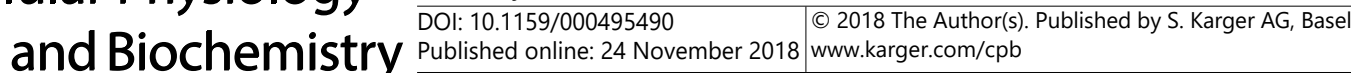 \\ Rentschler et al.: Argonaute 2 in Cytokine-Induced Senescence}

7 Michaloglou C, Vredeveld LC, Soengas MS, Denoyelle C, Kuilman T, van der Horst CM, Majoor DM, Shay JW, Mooi WJ, Peeper DS: BRAFE600-associated senescence-like cell cycle arrest of human naevi. Nature 2005;436:720-724.

-8 Collado M, Gil J, Efeyan A, Guerra C, Schuhmacher AJ, Barradas M, Benguría A, Zaballos A, Flores JM, Barbacid M, Beach D, Serrano M: Tumour biology: senescence in premalignant tumours. Nature 2005;436:642.

-9 Takaoka M, Harada H, Deramaudt TB, Oyama K, Andl CD, Johnstone CN, Rhoades B, Enders GH, Opitz OG, Nakagawa H: Ha-Ras(G12V) induces senescence in primary and immortalized human esophageal keratinocytes with p53 dysfunction. Oncogene 2004;23:6760-6768.

$\checkmark 10$ Schmitt CA, Fridman JS, Yang M, Lee S, Baranov E, Hoffman RM, Lowe SW: A senescence program controlled by 553 and p16INK4a contributes to the outcome of cancer therapy. Cell 2002;109:335-346.

11 Haferkamp S, Borst A, Adam C, Becker TM, Motschenbacher S, Windhövel S, Hufnagel AL, Houben $\mathrm{R}$, Meierjohann S: Vemurafenib induces senescence features in melanoma cells. J Invest Dermatol 2013;133:1601-1609.

-12 Braumüller H, Wieder T, Brenner E, Aßmann S, Hahn M, Alkhaled M, Schilbach K, Essmann F, Kneilling M, Griessinger C, Ranta F, Ullrich S, Mocikat R, Braungart K, Mehra T, Fehrenbacher B, Berdel J, Niessner $\mathrm{H}$, Meier F, van den Broek M et al.: T-helper-1-cell cytokines drive cancer into senescence. Nature 2013;494:361-365.

-13 Schilbach K, Alkhaled M, Welker C, Eckert F, Blank G, Ziegler H, Sterk M, Müller F, Sonntag K, Wieder T, Braumüller H, Schmitt J, Eyrich M, Schleicher S, Seitz C, Erbacher A, Pichler BJ, Müller H, Tighe R, Lim A et al.: Cancer-targeted IL-12 controls human rhabdomyosarcoma by senescence induction and myogenic differentiation. Oncoimmunology 2015;4:e1014760.

14 Hubackova S, Kucerova A, Michlits G, Kyjacova L, Reinis M, Korolov O, Bartek J, Hodny Z: IFN $\gamma$ induces oxidative stress, DNA damage and tumor cell senescence via TGF $\beta /$ SMAD signaling-dependent induction of Nox4 and suppression of ANT2. Oncogene 2016;35:1236-1249.

-15 Wieder T, Brenner E, Braumüller H, Bischof O, Röcken M: Cytokine-induced senescence for cancer surveillance. Cancer Metastasis Rev 2017;36:357-365.

16 Schreiber RD, Old LJ, Smyth MJ: Cancer immunoediting: integrating immunity's roles in cancer suppression and promotion. Science 2011;331:1565-1570.

17 Benhamed M, Herbig U, Ye T, Dejean A, Bischof O: Senescence is an endogenous trigger for microRNAdirected transcriptional gene silencing in human cells. Nat Cell Biol 2012;14:266-275.

18 Itahana K, Campisi J, Dimri GP: Methods to detect biomarkers of cellular senescence: the senescenceassociated beta-galactosidase assay. Methods Mol Biol 2007;371:21-31.

19 Friedrich K, Wieder T, von Haefen C, Radetzki S, Jänicke R, Schulze-Osthoff K, Dörken B, Daniel PT: Overexpression of caspase-3 restores sensitivity for drug-induced apoptosis in breast cancer cell lines with acquired drug resistance. Oncogene 2001;20:2749-2760.

-20 Ghashghaeinia M, Cluitmans JC, Toulany M, Saki M, Köberle M, Lang E, Dreischer P, Biedermann T, Duszenko M, Lang F, Bosman GJ, Wieder T: Age sensitivity of NFKB abundance and programmed cell death in erythrocytes induced by NFKB inhibitors. Cell Physiol Biochem 2013;32:801-813.

-21 Wieder T, Braumüller H, Brenner E, Zender L, Röcken M: Changing T-cell enigma: cancer killing or cancer control? Cell Cycle 2013;12:3146-3153.

22 Kim BS, Jung JS, Jang JH, Kang KS, Kang SK: Nuclear Argonaute 2 regulates adipose tissue-derived stem cell survival through direct control of miR10b and selenoprotein N1 expression. Aging Cell 2011;10:277-291.

-23 Stalder L, Heusermann W, Sokol L, Trojer D, Wirz J, Hean J, Fritzsche A, Aeschimann F, Pfanzagl V, Basselet P, Weiler J, Hintersteiner M, Morrissey DV, Meisner-Kober NC: The rough endoplasmatic reticulum is a central nucleation site of siRNA-mediated RNA silencing. EMBO J. 2013;32:1115-1127.

-24 Shen J, Xia W, Khotskaya YB, Huo L, Nakanishi K, Lim SO, Du Y, Wang Y, Chang WC, Chen CH, Hsu JL, Wu Y, Lam YC, James BP, Liu X, Liu CG, Patel DJ, Hung MC: EGFR modulates microRNA maturation in response to hypoxia through phosphorylation of AGO2. Nature 2013;497:383-387.

25 Yang M, Haase AD, Huang FK, Coulis G, Rivera KD, Dickinson BC, Chang CJ, Pappin DJ, Neubert TA, Hannon GJ, Boivin B, Tonks NK: Dephosphorylation of tyrosine 393 in argonaute 2 by protein tyrosine phosphatase $1 \mathrm{~B}$ regulates gene silencing in oncogenic RAS-induced senescence. Mol Cell 2014;55: 782-790. 


\section{Cellular Physiology Cell Physiol Biochem 2018;51:1103-1118

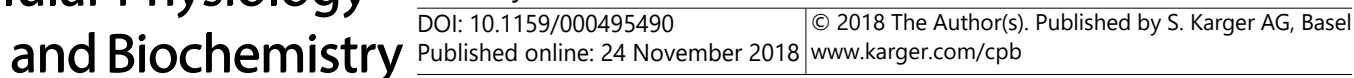

-26 Golden RJ, Chen B, Li T, Braun J, Manjunath H, Chen X, Wu J, Schmid V, Chang TC, Kopp F, Ramirez-Martinez A, Tagliabracci VS, Chen ZJ, Xie Y, Mendell JT: An Argonaute phosphorylation cycle promotes microRNAmediated silencing. Nature 2017;542:197-202.

-27 Parisi C, Giorgi C, Batassa EM, Braccini L, Maresca G, D'agnano I, Caputo V, Salvatore A, Pietrolati F, Cogoni C, Catalanotto C: Ago1 and Ago2 differentially affect cell proliferation, motility and apoptosis when overexpressed in SH-SY5Y neuroblastoma cells. FEBS Lett 2011;585:2965-2971.

28 Bian XJ, Zhang GM, Gu CY, Cai Y, Wang CF, Shen YJ, Zhu Y, Zhang HL, Dai B, Ye DW: Down-regulation of Dicer and Ago2 is associated with cell proliferation and apoptosis in prostate cancer. Tumour Biol 2014;35:11571-11578.

-29 Teteloshvili N, Smigielska-Czepiel K, Yuan Y, Seitz A, de Jong D, Rutgers B, Jellema P, van der Lei RJ, SlezakProchazka I, Brouwer E, Boots AM, Kroesen BJ, van den Berg A, Kluiver J: Argonaute 2 immunoprecipitation revealed large tumor suppressor kinase 1 as a novel proapoptotic target of miR-21 in T cells. FEBS J 2017;284:555-567.

- 30 Prokop A, Wrasidlo W, Lode H, Herold R, Lang F, Henze G, Dörken B, Wieder T, Daniel PT: Induction of apoptosis by enediyne antibiotic calicheamicin thetaII proceeds through a caspase-mediated mitochondrial amplification loop in an entirely Bax-dependent manner. Oncogene 2003;22:9107-9120.

-31 Wieder T, Eßmann F, Prokop A, Schmelz K, Schulze-Osthoff K, Beyaert R, Dörken B, Daniel, PT: Activation of caspase-8 in drug-induced apoptosis of B-lymphoid cells is independent of CD95/Fas receptor-ligand interaction and occurs downstream of caspase-3. Blood 2001;97:1378-1387.

-32 Kim SY, Ryu SJ, Kang HT, Choi HR, Park SC: Defective nuclear translocation of stress-activated signaling in senescent diploid human fibroblasts: a possible explanation for aging-associated apoptosis resistance. Apoptosis 2011;16:795-807.

-33 Baar MP, Brandt RMC, Putavet DA, Klein JDD, Derks KWJ, Bourgeois BRM, Stryeck S, Rijksen Y, van Willigenburg H, Feijtel DA, van der Pluijm I, Essers J, van Cappellen WA, van IJcken WF, Houtsmuller AB, Pothof J, de Bruin RWF, Madl T, Hoeijmakers JHJ, Campisi J, de Keizer PLJ. Targeted apoptosis of senescent cells restores tissue homeostasis in response to chemotoxicity and aging. Cell 2017;169:132-147.

34 Childs BG, Baker DJ, Kirkland JL, Campisi J, van Deursen JM: Senescence and apoptosis: dueling or complementary cell fates? EMBO Rep 2014;15:1139-1153.

-35 Demaria M, O'Leary MN, Chang J, Shao L, Liu S, Alimirah F, Koenig K, Le C, Mitin N, Deal AM, Alston S, Academia EC, Kilmarx S, Valdovinos A, Wang B, de Bruin A, Kennedy BK, Melov S, Zhou D, Sharpless NE et al.: Cellular Senescence Promotes Adverse Effects of Chemotherapy and Cancer Relapse. Cancer Discov 2017;7:165-176.

36 McHugh D, Gil J: Senescence and aging: Causes, consequences, and therapeutic avenues. J Cell Biol 2018;217:65-77.

-37 He S, Sharpless NE: Senescence in Health and Disease. Cell 2017;169:1000-1011.

-38 Chow MT, Möller A, Smyth MJ: Inflammation and immune surveillance in cancer. Semin Cancer Biol 2012;22:23-32.

-39 Kojima H, Inoue T, Kunimoto H, Nakajima K: IL-6-STAT3 signaling and premature senescence. JAKSTAT 2013;2:e25763.

40 Reimann M, Lee S, Loddenkemper C, Dörr JR, Tabor V, Aichele P, Stein H, Dörken B, Jenuwein T, Schmitt CA: Tumor stroma-derived TGF-beta limits myc-driven lymphomagenesis via Suv39h1-dependent senescence. Cancer Cell 2010;17:262-272. 